\title{
AN EXPERIMENTAL TEST OF THE GLUCOSTATIC THEORY OF REGULATION OF FOOD INTAKE ${ }^{1}$
}

\author{
By LIONEL M. BERNSTEIN AND MORTON I. GROSSMAN \\ (From the U. S. Army Medical Nutrition Laboratory, Fitssimons Army Hospital, \\ Denver, Colo.)
}

(Submitted for publication August 23, 1955; accepted January 30, 1956)

The most popular of the current hypotheses on regulation of food intake is the "glucostatic" theory proposed by Mayer (1). In essence this hypothesis states a) that "glucoreceptors" in the central nervous system (probably the hypothalamus) are sensitive to the rate at which they are utilizing glucose, b) that low utilization rates excite neural activity leading to hunger sensations and food-taking and high utilization rates produce the opposite effect, and c) that peripheral arterio-venous glucose differences serve as an index of utilization rates by the glucoreceptors in the central nervous system.

Blood glucose concentration and arterio-venous difference are known to rise following meals containing carbohydrate or protein and to fall to fasting levels during the post-absorptive period. From these facts it can be assumed $a$ priori that an association would be found to exist between blood glucose levels on the one hand and hunger, appetite and food-taking on the other. Whether this association reflects a causal relation between blood glucose and food-taking behavior is a problem for experimental solution. The most direct and the most critical means of attacking this problem experimentally would appear to be to study the effect of induced changes in blood glucose level (with their attendant changes in arterio-venous difference) on the quantity of food eaten under adequately controlled experimental conditions. This study was directed toward that end.

The study was divided into two parts : First, the effect of induced hyperglycemia on food intake; and second, the effect of induced hyperglycemia on subjective evaluation of appetite or desire to eat.

\footnotetext{
1 The opinions expressed in this paper are those of the authors and do not necessarily represent those of any governmental agency.
}

\section{METHOD}

\section{A. Effect of blood glucose levels on food intake}

Nine normal adult males (ages 19-22), conscientious objectors assigned to the Metabolic Research Division of the Medical Nutrition Laboratory, were used as test subjects.

Food consumption tests were performed every other day, three times weekly for three weeks, for a total of 9 tests on each subject. On the days of the tests the subjects consumed completely a fixed breakfast of 580 calories (Table I) served at 7:30 a.m. At 11:30 a.m. the test treatments were given. At 12:00 noon the subjects were offered the test meal which they were permitted to consume ad libitum.

The test treatments received were:

1. $200 \mathrm{ml}$. of 0.9 per cent sodium chloride solution by fine polyethylene stomach tube.

2. $200 \mathrm{ml}$. of 25 per cent glucose in water by fine polyethylene stomach tube.

3. $200 \mathrm{ml}$. of 0.9 per cent sodium chloride solution over a period of approximately 15 minutes by intravenous infusion.

4. $200 \mathrm{ml}$. of 10 per cent glucose in water over a period of approximately 15 minutes by intravenous infusion.

5. $200 \mathrm{ml}$. of 0.9 per cent sodium chloride solution containing $10 \mathrm{mg}$. of $\mathrm{DL}$-amphetamine by fine polyethylene stomach tube.

Each of the first four treatments was given twice and the fifth treatment once. Thus the treatments were coded $a$ through $i$ as follows:

$\begin{array}{ll}a & \text { Intragastric sodium chloride } \\ b & \text { Intragastric sodium chloride } \\ c & \text { Intragastric glucose } \\ d & \text { Intragastric glucose } \\ \boldsymbol{e} & \text { Intravenous sodium chloride } \\ \boldsymbol{f} & \text { Intravenous sodium chloride } \\ \boldsymbol{g} & \text { Intravenous glucose } \\ \boldsymbol{h} & \text { Intravenous glucose } \\ \boldsymbol{i} & \text { Intragastric DL-amphetamine }\end{array}$

The nine treatments ( $a$ through $i$ ) were given in randomized order using a 9 by 9 Latin square design. The subjects did not know what the test substances were.

To evaluate the effect of the test treatments on the arterial (capillary) and venous glucose levels and on the arteriovenous differences, specimens were obtained 
TABLE I

Test meals

\begin{tabular}{|c|c|c|}
\hline $\begin{array}{c}\text { Breakfast } \\
\text { (Fixed intake) }\end{array}$ & & $\begin{array}{c}\text { Dinner } \\
(A d \text { libitum })\end{array}$ \\
\hline $\begin{array}{l}\text { Frozen orange juice } \\
\text { Eggs, scrambled } \\
\text { Toast } \\
\text { Butter } \\
\text { Milk } \\
\text { Sugar } \\
\text { Coffee }\end{array}$ & $\begin{array}{r}185 \text { grams } \\
100 \text { grams } \\
25 \text { grams } \\
10 \text { grams } \\
240 \text { grams } \\
10 \text { grams }\end{array}$ & $\begin{array}{l}\text { Tenderloin steak } \\
\text { Potatoes, baked, skin } \\
\text { removed } \\
\text { Canned whole kernel } \\
\text { corn } \\
\text { Sliced tomatoes } \\
\text { Lettuce } \\
\text { Mayonnaise } \\
\text { Bread } \\
\text { Butter } \\
\text { Vanilla ice cream } \\
\text { Milk } \\
\text { Sugar } \\
\text { Coffee or tea }\end{array}$ \\
\hline
\end{tabular}

simultaneously by venipuncture without stasis on one arm and finger puncture on the other. The hand used for obtaining capillary blood was immersed in warm water for five minutes before puncture. Blood specimens were obtained immediately before test treatments, 30 minutes later (immediately before the test meal) and at the end of the test meal. Blood glucose was determined by the method of Nelson (2).

The test meal offered consisted of an appetizing selection of foods with a caloric value of approximately 1,500 (Table I). Additional portions of any or all items were available. The subjects were informed that they could consume as little or as much of each food as they wished. They were told that the purpose of the study was to evaluate the effect of meals on the blood glucose. They were unaware that the true purpose of the study was to evaluate the effect of blood glucose on food intake. Using careful weigh-backs, the amounts of all foods eaten were measured. The consumption of calories, protein, carbohydrate and fat were calculated using tabular values (3) except for steak for which values were derived by chemical analysis.

\section{B. Effect of blood glucose levels on appetite}

Twelve normal adult males, ages 19-31 (including the 9 subjects used in the study on food intake) were used as test subjects. Tests were performed on four successive days. On each test day, the subjects consumed a fixed breakfast of 400 calories at 6:00 a.m. At 10:30 a.m. the test treatments were given. The test treatments received were intravenous and intragastric saline and glucose described as treatments $1,2,3$, and 4 in section $A$, above. The four treatments were given in randomized order using a 4 by 4 Latin square design, repeated three times. The effect of the treatments on appetite was evaluated by questionnaires filled in by interviewers. Both test subjects and interviewers were unaware of which test treatments had been given. The responses to the questionnaire alternatives were graded numerically as follows :

$\begin{array}{ll}\text { No desire to eat } & 1 \\ \text { Could eat, but don't want to } & 2 \\ \text { Moderate desire to eat } & 3 \\ \text { Strong desire to eat } & 4 \\ \text { Extremely hungry } & 5\end{array}$

The subjects were questioned as to their appetites before breakfast (6:00 a.m.), hourly after breakfast until the test treatments $(6: 30,7: 30,8: 30,9: 30$, and $10: 30$ a.m. $)$, and at 20-minute intervals after the treatments for $1-1 / 2$ hours $(11: 00,11: 20,11: 40$ a.m., 12:00 noon, and 12:20 p.m.).

\section{RESULTS}

\section{A. Effect of blood glucose levels on food intake}

1. Blood glucose levels as affected by test treatments. The mean values of arterial (capillary), venous, and arterio-venous differences of blood glucose on the test treatments are summarized in Figure 1 and Table II. Blood No. 1 was obtained just prior to the test treatment, Blood No. 2 after the test treatment and just prior to the test meal, and Blood No. 3 following the test meal. Statistical analyses of the blood glucose levels were performed by the analysis of variance technique.

There were no significant differences of arterial $(A)$, venous $(\mathrm{V})$, or arterio-venous $(\mathrm{A}-\mathrm{V})$ dif-

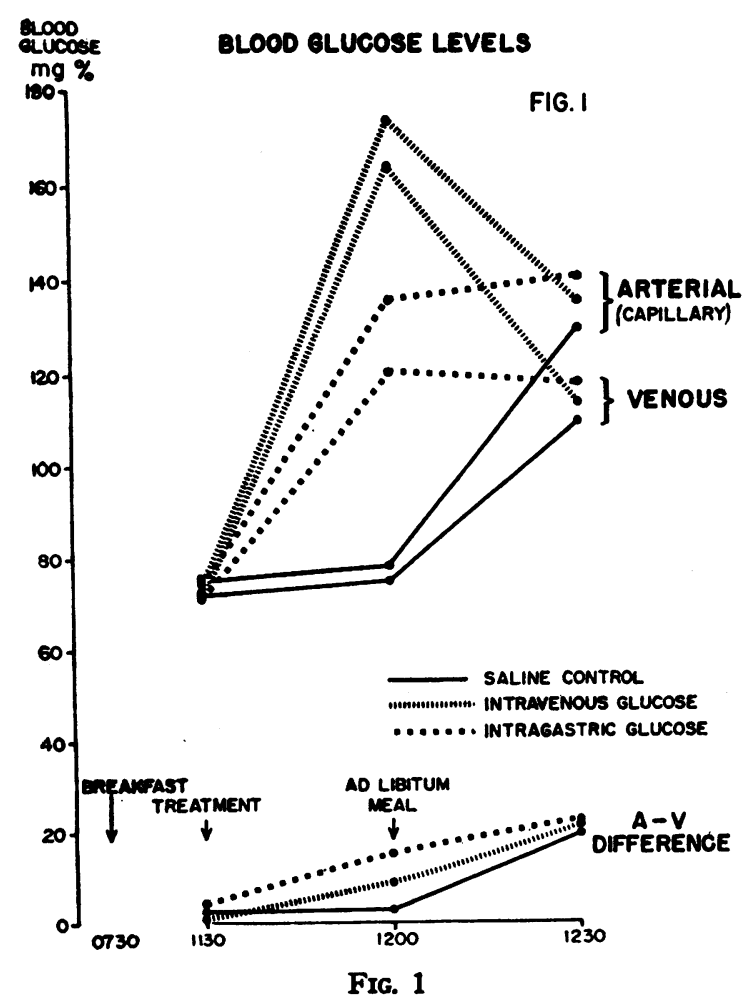




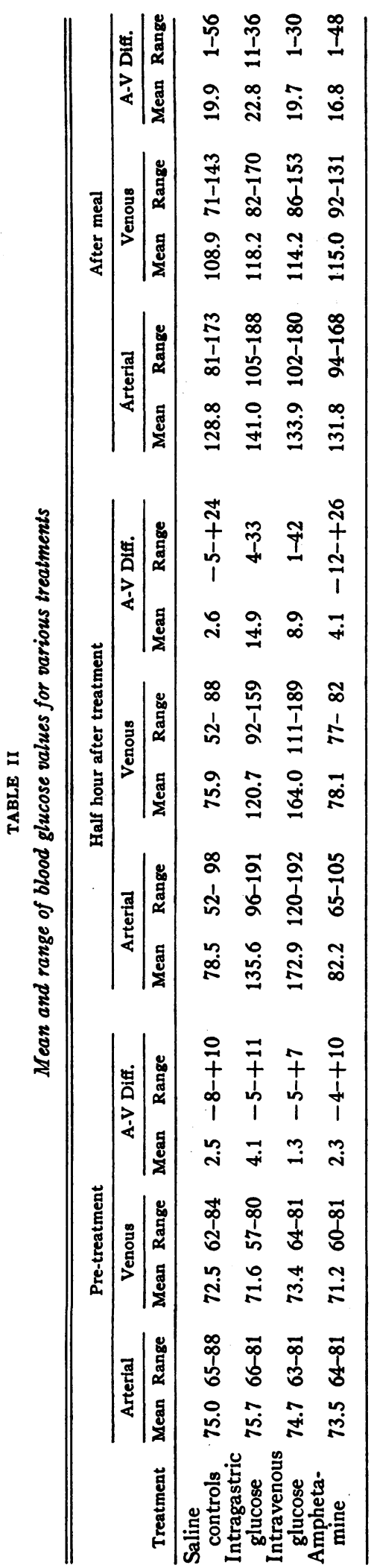

ferences of blood glucose levels in sample No. 1 on the various test treatments. This was expected because blood No. 1 was obtained before administration of the test treatments.

There were significant differences of sample No. 2 glucose values due to the test treatments. -No significant differences of $\mathrm{A}, \mathrm{V}$, or A-V differences were found between the four sets of duplicate treatments, or between intragastric saline and intravenous saline treatments. The intravenous glucose treatments resulted in significantly higher A $(P<.001), V(P<.001)$, and lower A-V $(P<.05)$ glucose values than did the intragastric glucose treatments. Lower $\mathrm{A}-\mathrm{V}$ differences on the intravenous treatment is explained by lower utilization rates following intravenous as compared with oral glucose administration. Such an effect has been reported in animals (4). The combined intravenous and intragastric glucose treatments resulted in significantly higher $\mathrm{A} \quad(\mathrm{P}<$ $.001), \mathrm{V}(\mathrm{P}<.001)$, and $\mathrm{A}-\mathrm{V}(\mathrm{P}<.001)$ glucose values than did the combined intravenous and intragastric saline test treatments. Thus, it is seen that the test treatments resulted in three distinct levels of arterial, venous, and arterio-venous differences of blood glucose values. The DLamphetamine treatment gave arterial and venous glucose values not significantly different from saline treatment alone.

Subsequent increases of A-V glucose differences resulted from the test meals following the treatments. These changes in Blood No. 3 glucose values are shown in Figure 1.

2. Food intake as affected by test treatments. The mean values of protein, fat, carbohydrate and total calories consumed in the ad libitum test meal

TABLE III

Mean ad libitum daily intake of protein, fat, carbohydrate, and total calories as related to test treatments

\begin{tabular}{|c|c|c|c|c|c|}
\hline \multirow{2}{*}{$\begin{array}{c}\text { Treat- } \\
\text { ment }\end{array}$} & \multicolumn{2}{|c|}{ Total calories } & \multirow{2}{*}{$\underset{\text { protein }}{\text { Gms }}$} & \multirow{2}{*}{$\underset{\text { fat }}{\text { Gms. }}$} & \multirow{2}{*}{ Gms. } \\
\hline & Mean & Range & & & \\
\hline $\begin{array}{l}a \\
b \\
c \\
d \\
e \\
f \\
g \\
h \\
i\end{array}$ & $\begin{array}{l}1,367 \\
1,280 \\
1,267 \\
1,253 \\
1,299 \\
1,296 \\
1,319 \\
1,265 \\
1,237\end{array}$ & $\begin{array}{r}1,048-1,785 \\
779-1,856 \\
911-1,724 \\
1,017-1,518 \\
911-1,844 \\
979-1,563 \\
895-1,607 \\
1,064-1,492 \\
980-1,401\end{array}$ & $\begin{array}{l}74.5 \\
67.7 \\
71.5 \\
69.1 \\
71.8 \\
73.9 \\
76.8 \\
70.7 \\
64.5\end{array}$ & $\begin{array}{l}60.3 \\
55.7 \\
55.2 \\
56.4 \\
56.3 \\
55.8 \\
55.6 \\
54.7 \\
57.6\end{array}$ & $\begin{array}{l}139.0 \\
122.9 \\
127.7 \\
125.4 \\
133.4 \\
131.7 \\
134.6 \\
129.2 \\
120.2\end{array}$ \\
\hline
\end{tabular}


TABLE IV

Analysis of variance of mean daily caloric intake of ad libitum meal as related to test treatments

\begin{tabular}{|c|c|c|c|c|}
\hline Variance source & $\begin{array}{l}\text { Degrees of } \\
\text { freedom }\end{array}$ & $\begin{array}{l}\text { Sums of } \\
\text { gquares }\end{array}$ & $\begin{array}{c}\text { Mean } \\
\text { square }\end{array}$ & $\mathbf{F}$ \\
\hline $\begin{array}{l}\text { Between treatments: } \\
a \text { vs. } b \\
c \text { vs. } d \\
e \text { vs. } f \\
g \text { vs. } h \\
(a+b) \text { vs. }(e+f) \\
(c+d) \text { vs. }(g+h) \\
\quad(a+b)+(e+f)) \text { vs. }((c+d)+(g+h)) \\
i \text { vs. }(a+b+c+d+e+f+g+h) \\
\text { Between men } \\
\text { Between days } \\
\text { Residual error }\end{array}$ & $\begin{array}{r}1 \\
1 \\
1 \\
1 \\
1 \\
1 \\
1 \\
1 \\
8 \\
8 \\
56\end{array}$ & $\begin{array}{r}33,973 \\
854 \\
25 \\
13,068 \\
5,954 \\
9,248 \\
21,081 \\
24,814 \\
2,207,111 \\
254,461 \\
1,205,269\end{array}$ & $\begin{array}{r}33,973 \\
854 \\
25 \\
13,068 \\
5,954 \\
9,248 \\
21,081 \\
24,814 \\
275,888 \\
31,807 \\
21,522\end{array}$ & $\begin{array}{c}1.58 \\
.04 \\
.001 \\
.61 \\
.28 \\
.43 \\
.98 \\
1.15 \\
12.82 \\
1.48\end{array}$ \\
\hline Total & 80 & $3,775,860$ & & \\
\hline
\end{tabular}

$* \mathrm{P}<0.01$.

are presented in Table III. The statistical analyses of these data by the analysis of variance method are presented in Tables IV and V. It is clear that the test treatments resulted in no significant differences of food intake in terms either of total calories or of the specific foodstuffs, protein, fat, or carbohydrate.

\section{B. Effect of blood glucose on "appetite"}

The means of the graded responses to the interrogation about intensity of "appetite" on the four test treatments are presented in Figure 2. Following breakfast there was a large decrease in "ap- petite" followed by a slow progressive increase in "appetite" for the next six hours. Analysis by the analysis of variance method revealed no significant difference between test-treatment groups at any time interval in the experiment, either before or after the test treatments.

\section{DISCUSSION}

\section{A. Effect of blood glucose levels on food intake}

It is clear that the test treatments did result in three distinct levels of arterial, venous and arterio-venous differences of blood glucose values

TABLE V

Analysis of oariance of protein, fat, and carbohydrate intake of ad libitum meal as related to test treatments

\begin{tabular}{|c|c|c|c|c|}
\hline Variance source & $\begin{array}{c}\text { Degrees of } \\
\text { freedom }\end{array}$ & $\begin{array}{l}\text { Sums of } \\
\text { squares }\end{array}$ & $\begin{array}{c}\text { Mean } \\
\text { square }\end{array}$ & $\mathbf{F}$ \\
\hline $\begin{array}{l}\text { i) Protein } \\
\text { Between men } \\
\text { Between days } \\
\text { Between treatments } \\
\text { Residual error }\end{array}$ & $\begin{array}{r}8 \\
8 \\
8 \\
56\end{array}$ & $\begin{array}{r}9,269.85 \\
776.72 \\
838.01 \\
3,777.28\end{array}$ & $\begin{array}{r}1,158.73 \\
97.09 \\
104.75 \\
67.45\end{array}$ & $\begin{array}{c}17.18^{*} \\
1.44 \\
1.55\end{array}$ \\
\hline Total & 80 & $14,661.86$ & & \\
\hline 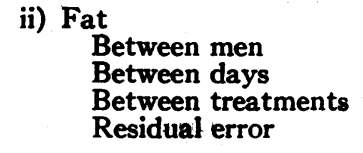 & $\begin{array}{r}8 \\
8 \\
8 \\
56\end{array}$ & $\begin{array}{r}8,464.02 \\
488.38 \\
196.72 \\
2,520.56\end{array}$ & $\begin{array}{r}1,058.00 \\
61.05 \\
24.59 \\
45.01\end{array}$ & $\begin{array}{c}23.51 * \\
1.36 \\
0.55\end{array}$ \\
\hline Total & 80 & $11,669.68$ & & \\
\hline $\begin{array}{l}\text { iii) Carbohydrate } \\
\text { Between men } \\
\text { Between days } \\
\text { Between treatments } \\
\text { Residual error }\end{array}$ & $\begin{array}{r}8 \\
8 \\
8 \\
56\end{array}$ & $\begin{array}{r}17,462.66 \\
3,070.16 \\
2,577.94 \\
18,611.99\end{array}$ & $\begin{array}{r}2,182.83 \\
383.77 \\
322.24 \\
332.36\end{array}$ & $\begin{array}{l}6.57^{*} \\
1.15 \\
0.97\end{array}$ \\
\hline Total & 80 & $41,722.75$ & & \\
\hline
\end{tabular}




\section{EFFECT OF INTRAVENOUS OR INTRAGASTRIC GLUCOSE ON "APPETITE"}

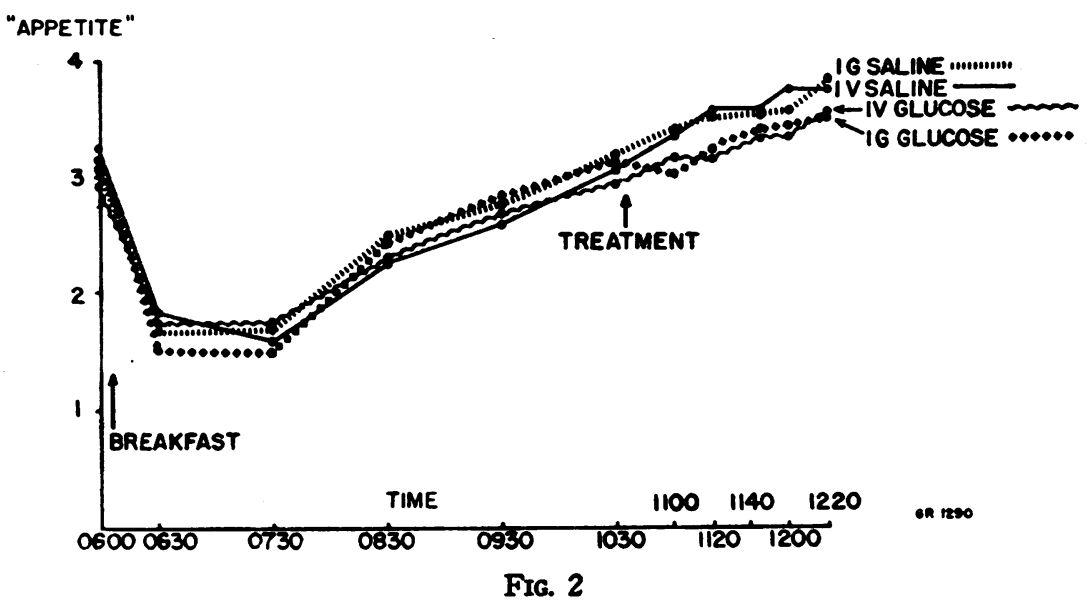

at the time of the test meal. Despite this, the amount of test-meal calories consumed did not differ significantly between the treatments. Likewise the relative amounts of protein, fat, and carbohydrate consumed were not altered by test treatments. The possibility that under these experimental circumstances the peripheral $\mathrm{A}-\mathrm{V}$ glucose difference does not reflect the utilization of glucose by the "Glucostatic center" cannot clearly be refuted, but, in the absence of evidence to the contrary, it is reasonable to assume that the hyperglycemia and increased $\mathrm{A}-\mathrm{V}$ difference induced by the treatments is comparable to that which results from ingestion of meals. Another possibility is that elevated $\mathrm{A}-\mathrm{V}$. differences must be sustained for longer periods before they influence foodtaking behavior; however, in the studies of Van Itallie, Beaudoin, and Mayer (5) the onset of hunger was reported to follow declines in $\mathrm{A}-\mathrm{V}$ difference promptly and Stunkard and Wolff (6) reported that intravenous injection of glucose led to prompt abolition of gastric hunger contractions and hunger sensations. Still another possibility is that through some elements in the design of the study the effect of unrecognized psychic factors exerted a predominant effect on food-taking and appetite so that the normal regulatory influence of glucose was obscured. Such objections must be stated in a manner susceptible to experimental analysis before they can be evaluated.

The limitations of the use of peripheral $A-V$ glucose differences as an index of the glucose metabolism of the central glucoreceptors concerned with regulation of food intake have been pointed out by Mayer (7). In the present study these peripheral blood glucose studies serve mainly to demonstrate that the glucose treatments had their anticipated effect. Quite apart from any studies on blood glucose, it is reasonable to assume that if alterations in glucose metabolism produced by ingestion of food are concerned with regulation of hunger and appetite, then comparable changes induced by administration of glucose should mimic these effects.

Studies on the effect of hyperglycemia on food intake in animals have been reviewed elsewhere (8).

\section{B. Effect of DL-amphetamine}

DL-amphetamine and dexedrine are commonly used in the treatment of obesity because they are believed to reduce food intake. In this study, the DL-amphetamine treatment did not significantly decrease food intake as compared with all other glucose and saline test treatments. This failure of DL-amphetamine to decrease food intake is contrary to the effects reported in both animals and humans. The dose of amphetamine required to suppress food intake in animals is considerably higher, per unit of body weight, than that used in man. There are numerous clinical reports of the efficacy of amphetamine as an anorexigenic compound in man (9-19) but these are all based on weight loss in obese subjects. There is only one report of the anorexic effect of amphetamine which is supported by food intake measurement data, and 
in that study the effect of amphetamine was confounded with time (20).

It may be noted that in our data the caloric intake following amphetamine treatment was the lowest of all nine treatments, though not statistically significantly so. Perhaps a significant anorexic effect of amphetamine might be demonstrated by a test involving repeated administration. A definitive answer to the problem by additional experiments is awaited.

\section{Effect of blood glucose levels on "appetite"}

From Figure 2, it can be seen that no significant differences of "appetite" occurred on the intravenous or intragastric saline and glucose treatments. The failure to find significant differences between test groups before treatments serves as a test of the validity of the questionnaire method used. The large decrease of "appetite" caused by ingestion of a small breakfast further indicates the sensitivity of the questionnaire method. The blood glucose values were not actually determined in this phase of the study. It was assumed that the same elevation of arterial, venous, and arteriovenous differences of blood glucose values occurred with these treatments as were described for the same treatments in section A of Results. It is concluded, therefore, that the arterial, venous, and arterio-venous differences of blood glucose values had no effect on "appetite" under the conditions of this study. This corroborates the findings of the effects of blood glucose on food intake.

A detailed account of the results of this study is presented in Medical Nutrition Laboratory Report No. 165, 10 May 1955.

\section{SUMMARY AND CONCLUSIONS}

Nine young adult male subjects received glucose intravenously or intragastrically. Arterial (capillary), venous, and arterio-venous differences in blood glucose levels showed the elevations expected to occur after such treatments. Consumption of food (in terms of calories, protein, carbohydrate and fat) during the period of hyperglycemia was not significantly different from control days on which saline treatments were given.

Twelve young adult male subjects received glucose treatments as described above. The inten- sity of appetite (desire for food) as measured by a graded scale of a questionnaire was not significantly altered by the glucose treatments when these were compared with saline-control treatments.

The results of these experiments do not support the "glucostatic hypothesis" of Mayer.

\section{ACKNOWLEDGMENT}

The technical assistance of Jacqueline $H$. Sellars, Florence Berger, Virginia McGary, Mary C. Tkacik, Janet A. Rogers, Thomas Hutton, Floyd Williford, Jr., Thomas B. Jenkins, Walter L. Neumaier, Sylvester Griffin, Howard K. Cahall, and Eugene A. Francis, is gratefully acknowledged.

\section{REFERENCES}

1. Mayer, J., Genetic, traumatic and environmental factors in the etiology of obesity. Physiol. Rev., 1953, 33, 472.

2. Nelson, N., A photometric adaptation of the Somogyi method for the determination of glucose. J. Biol. Chem., 1944, 153, 375.

3. Watt, B. K., and Merrill, A. L., Composition of foods : raw, processed, prepared. United States Department of Agriculture Handbook No. 8, 1950.

4. Scow, R. O., and Cornfield, J., Quantitative relations between the oral and intravenous glucose tolerance curves. Am. J. Physiol., 1954, 179, 435.

5. Van Itallie, T. B., Beaudoin, R., and Mayer, J., Arteriovenous glucose differences, metabolic hypoglycemia and food intake in man. J. Clin. Nutrition, 1953, 1, 208.

6. Stunkard, A. J., and Wolff, H. G., Correlation of arteriovenous glucose differences, gastric hunger contractions and the experience of hunger in man. Federation Proc., 1954, 13, 147.

7. Mayer, J., Regulation of energy intake and the body weight: The glucostatic theory and the lipostatic hypothesis. Ann. New York Acad. Sc., 1955, 63, 15.

8. Grossman, M. I., Integration of current views on the regulation of hunger and appetite. Ann. New York Acad. Sc., 1955, 63, 76.

9. Adlerberg, D., and Mayer, M., Results of prolonged medical treatment of obesity with diet alone, diet and thyroid preparations, and diet and amphetamine. J. Clin. Endocrinol., 1949, 9, 275.

10. Colton, N. H., Segal, H. I., Steinberg, A., Shechter, F. R., and Pastor, N., The management of obesity with emphasis on appetite control. Am. J. M. Sc., 1943, 206, 75.

11. Coopersmith, B. I., Dexedrine and weight control in pregnancy. Am. J. Obst. \& Gynec., 1949, 58, 664.

12. Edwards, D. A. W., and Swyer, G. I. M., The comparative values of dextroamphetamine sulphate, 
dried thyroid gland, and a placebo in the treatment of obesity. Clin. Sc., 1950, 9, 115.

13. Freed, S. C., and Mizel, M., The use of amphetamine combinations for appetite suppression. Ann. Int. Med., 1952, 36, 1492.

14. Gelvin, E. P., and McGavack, T. H., Dexedrine and weight reduction. New York State J. Med., 1949, 49, 279.

15. Gelvin, E. P., McGavack, T. H., and Kenigsburg, S., The anorexigenic effect of sustained-release dexedrine preparations. Am. J. Digest. Dis., 1953, 20, 307.

16. Hawirko, L., and Sprague, P. H., Treatment of obesity by appetite-depressing drugs. Canad. M. A. M., 1946, 54, 26.
17. Osserman, K., and Dolger, H., Obesity in diabetes: A study of therapy with anorexigenic drugs. Ann. Int. Med., 1951, 34, 72.

18. Roberts, E., The treatment of obesity with an anorexigenic drug. Ann. Int. Med., 1951, 34, 1324.

19. Williams, R. H., Daughaday, W. H., Rogers, W. F., Jr., Asper, S. P., Jr., and Towery, B. T., Obesity and its treatment, with particular reference to the use of anorexigenic compounds. Ann. Int. Med., 1948, $29,510$.

20. Harris, S. C., Ivy, A. C., and Searle, L. M., The mechanism of amphetamine-induced loss of weight. A consideration of the theory of hunger and appetite. J. A. M. A., 1947, 134, 1468. 